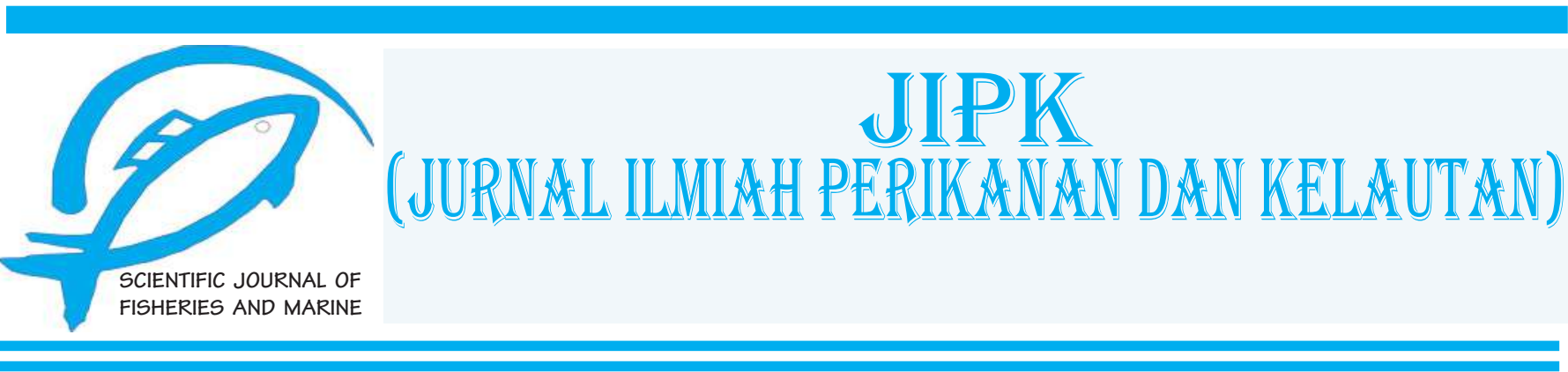

Research Article

\title{
Flora Fauna Biodiversity and CSR Implementation in the Mangrove Ecosystem of Bagan Serdang Village, North Sumatra Province.
}

\author{
Ahmad Muhtadi $^{(1 D}$, Rusdi Leidonald ${ }^{1}$, Kamto Triwibowo², Nurul Azmi² \\ ${ }^{1}$ Program Studi Manajemen Sumber Daya Perairan, Fakultas Pertanian, Universitas Sumatera Utara, Medan. Indonesia \\ ${ }^{2}$ PT Pertamina (Persero) TBBM Medan Group, Medan. Indonesia
}

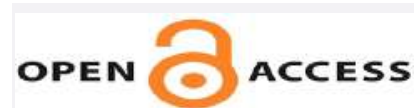

\section{ARTICLE INFO}

Received: Desember 25, 2019

Accepted: January 22, 2020

Published: March 11, 2020

*) Corresponding author:

E-mail: ahmad.muhtadi@usu. ac.id

\section{Keywords:}

biodiversity

corporate social responsibility mangrove

This is an open access article under the CC BY-NC-ND license (http://creativecommons.org/licenses/by-nc-nd/4.0/)

\begin{abstract}
Information about mangrove and fauna biodiversity in Bagan Serdang Village is essential to be studied as a basis for assessing the management and utilization potential of mangrove. This information could be used as a reference in sustainable mangrove management. This study aims to determine the biodiversity of flora and fauna in the mangrove ecosystem of Bagan Serdang Village. The research location is divided into three areas, with three observation points. The study was conducted in August-September 2019. The sampling of mangroves was carried out using the Spot Check Method. The results showed that the types of mangroves found were 18 species from 12 families consisting of 14 species of true mangrove and four types of associated mangroves while the fauna found in the mangrove ecosystem of Bagan Serdang Village was 16 species of fish, nine species of crustaceans, 13 species of mollusks, four species of birds, one species of reptile, one species of mammal and one species of horse shoe crab. The results of the mangroves analysis in the Bagan Serdang Village's mangrove ecosystem, including in moderate heading to damage condition. This could be seen from the death of several trees and the flourishing of A. ilicifolius species as a marker of mangrove, which tends to be damaged. The diversity of mangroves in the Bagan Serdang Village is lower (1.63) compared to aquatic organisms that reach 2.09 - 2.44. Corporate responsibility or CSR that PT Pertamina (Persero) TBBM Medan Group carried out in the village of Bagan Serdang with mangrove planting activities and ecotourism, as well as the development of processed mangrove products, could increase the value of diversity and increase the economy of the surrounding community.
\end{abstract}

Cite this as: Muhtadi, A., Leidonald, R., Triwibowo, K., \& Azmi, N. (2020). Flora Fauna Biodiversity and CSR Implementation in the Mangrove Ecosystem of Bagan Serdang Village, North Sumatra Province. Jurnal Ilmiah Perikanan dan Kelautan, 12(1):5972. http://doi.org/10.20473/jipk.v12i1.17120 


\section{Introduction}

The existence of mangroves is very important as a life support system for various aquatic and terrestrial organisms, either as a feeding ground, nursery ground, or as a spawning ground. On the other hand, socio-economically, mangrove ecosystems are source of livelihood for coastal communities. In addition, mangrove ecosystems contribute to controlling the global climate through carbon sequestration (Rangkuti et al., 2017). Damage to mangrove ecosystems will have an impact on the loss of habitat of various organisms in coastal and estuary ecosystems. This will have a direct impact on the loss of various flora and fauna species associated with mangrove ecosystems (Giessen et al., 2012; Rangkuti et al., 2017). Moreover, it will also have an impact on the economy of the surrounding community (Muhtadi et al., 2015).

Mangrove was one of the mega biodiversity in Indonesia. Giessen et al. (2012), reported that there were at least 202 species of mangroves found in Indonesia. These mangroves spread on the coast of Indonesia, both on the main island and on small islands (Rangkuti et al., 2017). The area of Indonesian mangroves is the largest mangrove in the world. Indonesia has $23 \%$ of the world's mangroves, with an area of 3.4 million $\mathrm{Ha}$ (KLHK, 2017). This area is slightly higher than the results of the mapping of the Center for Marine Natural Resource Survey (PSSDAL) -Bakosurtanal by analyzing Landsat ETM image data (accumulation of image data in 2006-2009), stating mangrove area in Indonesia around 3,244,018.46 Ha (Hartini et al., 2010). Mangroves in North Sumatra are mostly found in the East Coast region, parts of the west coast of Sumatra, and small islands on the west coast of North Sumatra (Anonimous, 2018a). The east coast region of North Sumatra itself has a $545 \mathrm{~km}$ long coastline with an area of 74,417.80 ha (KLH, 2012a; North Sumatra DKP, 2015). The mangrove stretches from the east coast of Langkat Regency to the South Labuhan Batu District with varying thickness (Anonimous, 2018a).

However, mangroves in North Sumatra are only $8.16 \%$ in the good category, and the rest are in bad condition (KLH, 2012). This is not much different from the conditions in Indonesia where mangroves have been damaged a lot, which is only around $57.90 \%$ of mangroves are in good condition, and the rest are damaged (KLHK, 2017). The mangroves damaged, especially on the east coast of North Sumatra is caused by land clearing or conversion of forests to fishponds, settlements, industries, and plantations (especially oil palm) $(\mathrm{KLH}$, 2012; Rangkuti et al., 2017). In addition to conversion, destruction of mangrove forests as cattle fodder, as well as mining of sea sand along the coast in front of the mangrove forest area (Rangkuti et al., 2017).

PT Pertamina (Persero) Fuel Terminal Medan Group, as it is responsible for environmental sustainability, holds a role in protecting and preserving the environment, especially the mangrove area in North Sumatra, through Corporate Social Responsibility (CSR). One of the programs is the Community Empowerment of Bagan Serdang Mangrove Village, Deli Serdang Regency, North Sumatra Province, which began in 2018. The mangrove forest area of Bagan Serdang Village has an area of around 26.10 Ha (Anonimous, 2018b) with the condition of mangrove that is quite apprehensive with the damaged forest and land coverage which is getting lower. This program is one of PT Pertamina's efforts in protecting the environment (mangroves) and to improve the welfare and community awareness of the environment. This is in line with the Biodiversity Park Program, which was rolled out by the Ministry of Forestry and the Environment. Biodiversity itself has a goal as a reserve area for local biological natural resources outside the forest area that has an in-situ and/ or ex-situ conservation function and to save a variety of native/local plant species that have a very high level of threat to its preservation or threats that result extinction (Minister of Environment Regulation No. 3 of 2012). To date, there have been 73 parks built throughout Indonesia (KLHK, 2015).

Therefore, the presence of the Bagan Serdang mangrove area is expected to have a greater role in the form of environmental conservation and community institutional strengthening through community involvement in area management. The existence of the Bagan Serdang mangrove area is also expected to have an impact on improving the community's economy through ecotourism services and fishing (fish, shrimp, and crab) and mangrove culinary (mangrove processed food) businesses. The management of the Bagan Serdang mangrove area is also expected to open opportunities for developing partnerships with various parties. This study will provide information on the biodiversity of flora and fauna in mangrove ecosystems and the role of an overview of the implementation of PT Pertamina (Persero) Fuel Terminal Medan Group CSR program in mangrove management efforts in North Sumatra, specifically in Bagan Serdang mangrove area, Deli Serdang Regency, North Sumatra Province.

\section{Materials and Methods}

\subsection{Place and Time}

This research was conducted in Bagan Serdang Village, Deli Serdang Regency, North Sumatra Province, in August - September 2019. 


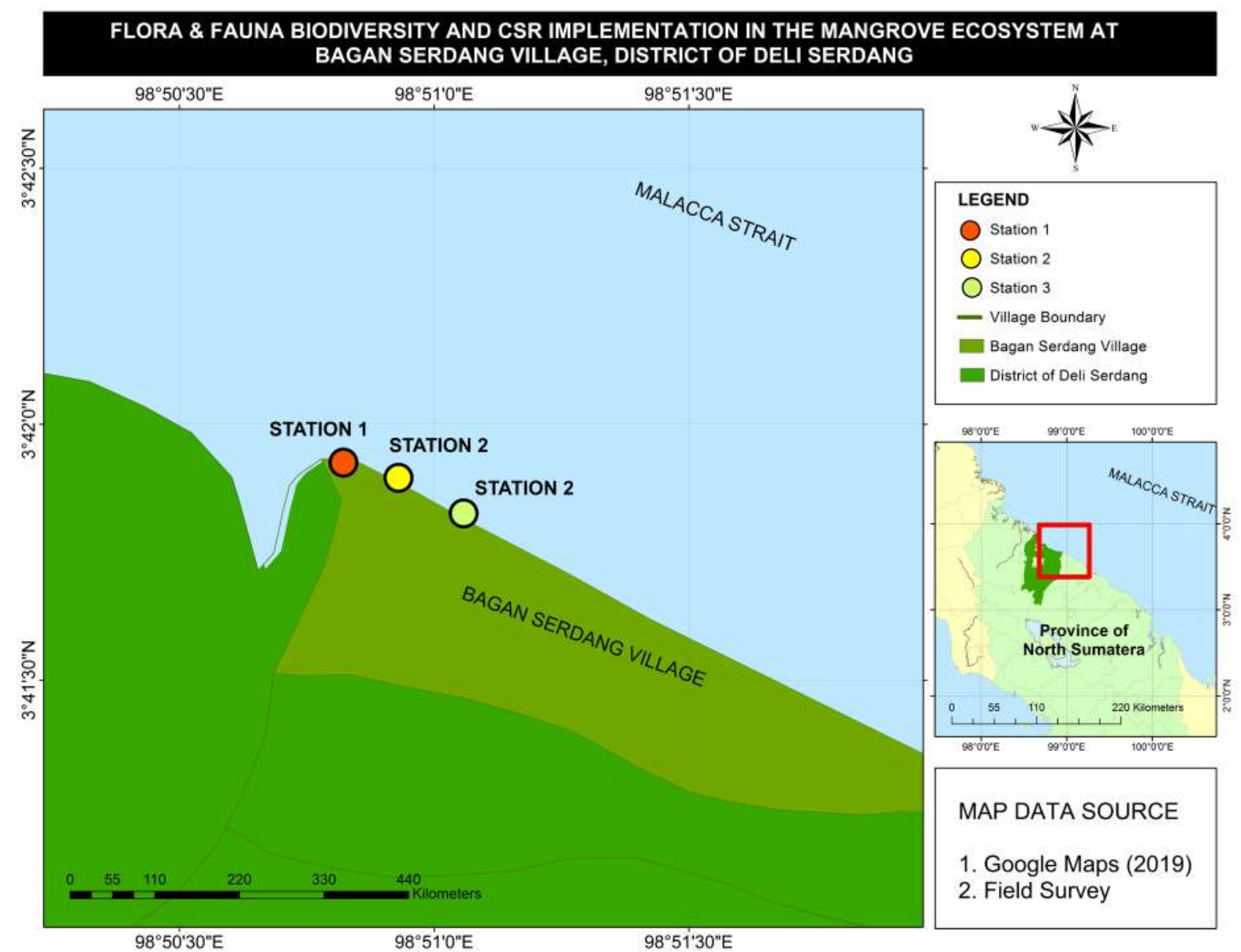

Figure 1. The map of research location

The instruments used in this study were Oregon 65 Garmin GPS with accuracy up to $3 \mathrm{~m}$, fabric meter to measure mangrove's trunk, roll meter for transects measurement, and stationery and questionnaires for community interviews. Map of data collection presented in Figure 1.

\subsection{Mangrove data collection}

Determination of transect observations carried out by the Spot Check Method (Bengen, 2004). The observation point consists of three points along the coastline. At each point, the transect is pulled perpendicular from the direction of the sea to the land along 50 meters by three lines with a distance between the tracks 50-100 meters. At each transect, vegetation data is sampled in $10 \mathrm{~m} \times 10 \mathrm{~m}$ transects plot. In each plot, measure the mangrove's trunk diameter of each tree on the transect. Identification of mangrove plants based on Giesen et al. (2012) guidelines.

\subsection{Retrieval of Fauna Data}

For Mollusca data, sampling is done by observing the $1 \mathrm{~m} \times 1 \mathrm{~m}$ transect inside the observation mangrove spot. Sampling of fish and crustaceans were done by observing fishermen's catches around the observation point. Furthermore, bird sampling was carried out in the morning and evening with the help of the Nikon B700 long shoot camera. Fish identification refers to Kottelat et al. (1993) and Carpenter and Niem (1998). Further identification of crustaceans and molluscs refers to Carpenter and Niem (1998) and Dharma (2005).

\subsection{Retrieval of CSR Implementation Data}

CSR implementation data, especially the economic improvement of the surrounding community, was carried out with in-depth interviews with economic actors that had been formed and fostered by PT Pertamina (Persero) Fuel Terminal Medan Group in 2018. The fostered groups were the Tourism Awareness Group (Darwis), the Environmental Awareness Group (Darling), Family Welfare Empowerment (PKK), and community 
surveillance group (P2WK) with each groups consisting of four people (16 respondens).

\subsection{Data Analysis}

Data analyss used to determine the condition of mangrove forests by analyzing species density, species frequency, land coverage, and species importance value (Bengen, 2004). Mangrove status refers to the Ministry of Environment regulation No. 201 of 2004 concerning Standard Criteria and Guidelines for Mangrove Damage Determination (KLH, 2004). Related to the biodiversity index analyzed consists of diversity index (H'), uniformity $(\mathrm{E})$, and dominance $(\mathrm{C})$, which refers to Odum (1996) and Krebs (2014). Relating to economic data and CSR implementation is carried out descriptively from the findings in the field.

Flora and fauna diversity was calculated using the diversity index of Krebs (2014) with the following formula:

$\mathrm{H}^{\prime}=-\left(\sum\right.$ pi $\log _{2}$ pi $)$

Where:

$\mathrm{H}^{\text {‘ }} \quad=$ species diversity index,

ni = Number of individuals of each species,

$\mathrm{N} \quad=$ Number of all individuals

$\mathrm{Pi}=$ Important Probability for each species $=\mathrm{ni} / \mathrm{N}$,

The equitability index (E) was calculated by following the equation (Krebs, 2014):

$\mathrm{E}=\mathrm{H}^{\prime} / \mathrm{H}^{\prime} \max$

Where:

$\mathrm{E}=$ Shannon-Wienner uniformity index,

$\mathrm{H}=$ Species balance,

H’max $=$ maximum diversity index $\left(\log _{2} \mathrm{~S}\right)$,

$\mathrm{S} \quad=$ Total number of species

The dominance index is calculated according to the Simpson index in Odum (1996).

$\mathrm{C}=\sum\left(^{2}\right.$

Where:

$\mathrm{C}=$ Index of dominance,

ni = Number of individuals of each species,

$\mathrm{N}=$ total individual community

Mangrove Importance Index is calculated by the formula (Bengen, 2004):

$\mathrm{MII}=\mathrm{RD}+\mathrm{RF}+\mathrm{RC}$

Where:

MII = Mangrove Importance Index
$\mathrm{RD}=$ Relative density

$\mathrm{RF} \quad=$ Relative frequency

$\mathrm{RC} \quad=$ Realitve covering

Relative density calculated by:

$\mathrm{DR}=\frac{(\text { tree density to-i) }}{(\text { density of entire tree })} \times 100 \%$

with Density $(\mathrm{D})=($ the number of trees to-i)

(sample plot area)

Relative frequency calculated by:

$\mathrm{FR}=($ the frequency of the $\mathrm{i}-\mathrm{th}$ species $) \times 100 \%$

(total number of tree frequencies)

with Frequency $(\mathrm{F})=$

( $\sum$ the number of plots found in the i-th species)

(total number of observation plots)

Relative covering calculated by:

$$
\mathrm{C}=\frac{\left(\sum \mathrm{BA}\right)}{\mathrm{A}}
$$

where :

$$
\begin{array}{ll}
\mathrm{C} & =\text { covering } \\
\mathrm{BA} & =\text { Tree base area } \\
\mathrm{A} & =\text { sample plot area }
\end{array}
$$

$\left(1 / 4 \pi d^{\wedge} 2\right)$ with the value of $\pi=3,1416$

$\mathrm{CR}=\frac{(\text { the relative area of the } \mathrm{i}-\text { th tree })}{\text { (covering of entire tree) }} \times 100 \%$

\section{Results and Discussion}

\subsection{Mangrove Species Composition}

There are 18 mangrove species from 12 families found in the Mangrove Ecosystems in Bagan Serdang Village. These mangroves consist of 13 true mangroves and five associated mangroves (Table 1). The Rhizo phoraceae family is the most common mangrove species found. The observation of mangroves in the Bagan Serdang Village mangrove ecosystem found that the Rhizophoraceae family had more species, as many as four species. Muhtadi et al. (2016; 2020a) found seven species of the Rhizophoraceae family in the Sambilan 
JIPK. Volume 12 No 1. April 2020 / Flora Fauna Biodiversity and CSR Implementation in the Mangrove Ecosystem ....

Table 1. Mangroves species found in mangrove ecosystem on Bagan Serdang Village

\begin{tabular}{|c|c|c|c|c|c|}
\hline No & Family & Species & Indonesia name & Local name & Annotation \\
\hline 1 & Acanthaceae & Acanthus ilicifolius & Jeruju & Jeruju & - \\
\hline 2 & Arecaceae & Nypa fruticans & Nipah & Nipah & 1 \\
\hline 3 & Asteraceae & Wedelia biflora & - & Beluntas & mangrove \\
\hline 4 & Avicenniaceae & Avicennia lanata & Api -api & Api-api & - \\
\hline 5 & Combretaceae & Lumnitzera littorea & Teruntum & - & - \\
\hline 6 & Combretaceae & Lumnitzera racemosa & Teruntum & Teruntum & - \\
\hline 7 & Combretaceae & Terminalia catappa & Ketapang & - & \multirow{2}{*}{ Associate mangrove } \\
\hline 8 & Gentianaceae & Fagraea crenulata & Ketapang & Birah -birah & \\
\hline 9 & Lecythidaceae & Barringtonia asiatica & Putat & Putat & True \\
\hline 10 & Euphorbiaceae & Excoecaria agallocha & Mata buta/ Garu & Buta-buta & mangrove \\
\hline 11 & Malvaceae & Thespesia populnea & Waru laut & - & Associate mangrove \\
\hline 12 & Pteridaceae & Acrostichum aureum & Paku laut & Piai & - \\
\hline 13 & Rhizophoraceae & Bruguiera hainessii & Tancang & Tanjang & - \\
\hline 14 & Rhizophoraceae & Ceriops tagal & Tengar & - & 1 \\
\hline 15 & Rhizophoraceae & Rhizophora mucronata & Bakau besar & Bako & mangrove \\
\hline 16 & Rhizophoraceae & Rhizophora stylosa & Bakau merah & Bako kurap & - \\
\hline 17 & Sonneratiaceae & Sonneratia caesolaris & Pedada & Berembang & - \\
\hline 18 & Sonneratiaceae & Sonneratia ovata & Pedada & Pedada & - \\
\hline
\end{tabular}

Island and Central Tapanuli Conservation Area. The most frequently found mangrove species are A. lanata, B. hainessi, and A. ilicifolius.

There are some mangroves and coastal vegetation which are rarely found elsewhere but are found in Bagan Serdang Village, namely B. asiatica and $F$. crenulata. Based on a search of several studies on the east coast of Sumatra including Indonesia, the two species were not found (Onrizal and Kusmana, 2010; Sitompul et al., 2014; Hutabarat et al., 2015; Muhtadi et al., 2016). Both species have only been discovered by Muhtadi et al. (2020b) in the tidal lake ecosystem in Medan Marelan. $B$. asiatica is a true mangrove while $F$. crenulata is a secondary mangrove (coastal vegetation) which is similar to ketapang ( $T$. catappa). The difference between $T$. catappa and $F$. crenulata is the presence of a bulge (thorn in sapling) in $F$. crenulata while in T. catappa there is none.

Mangrove species found in the Mangrove Ecosystem of Bagan Serdang Village are quite a lot compared to other areas based on several existing reports. This shows that mangroves in the Mangrove Ecosystem of Bagan Serdang Village have a relatively high species compared to other places. As reported by Sitompul et al. (2014) found eight species of mangroves in Bali Beach, Batubara Regency, Hutabarat et al. (2015) found five types. In other regions, Samsumarlin et al. (2015) in Umbele, Morowali, with 17 species. 
Table 2. Mangroves Important Index

\begin{tabular}{|c|c|c|c|c|c|c|}
\hline Species & $\begin{array}{l}\text { Density } \\
\text { (tree/ha) }\end{array}$ & $\begin{array}{l}\text { Covering } \\
\left(\mathrm{cm}^{2} / \mathbf{h a}\right)\end{array}$ & $\begin{array}{l}\text { Relative } \\
\text { density }\end{array}$ & $\begin{array}{l}\text { Relative } \\
\text { Frequency }\end{array}$ & $\begin{array}{l}\text { Relative } \\
\text { Covering }\end{array}$ & IVI \\
\hline Acanthus ilicifolius & 153 & 2.65 & 12.03 & 10.71 & 10.23 & 32.97 \\
\hline Acrostichum aureum & 63 & 2.85 & 5.2 & 8.95 & 8.56 & 22.72 \\
\hline Avicennia lanata & 217 & 12.98 & 18.25 & 11.68 & 11.18 & 41.1 \\
\hline Barringtonia asiatica & 7 & 0.23 & 0.57 & 1.33 & 1.28 & 3.19 \\
\hline Bruguiera hainessii & 187 & 2.65 & 14.5 & 10.71 & 10.23 & 35.44 \\
\hline Ceriops tagal & 13 & 0.47 & 1.17 & 1.33 & 1.28 & 3.79 \\
\hline Excoecaria agallocha & 53 & 2.52 & 4.68 & 5.44 & 5.23 & 15.36 \\
\hline Fagraea crenulata & 17 & 0.78 & 1.42 & 1.33 & 1.28 & 4.04 \\
\hline Lumnitzera littorea & 23 & 0.44 & 1.87 & 3.14 & 3 & 8.02 \\
\hline Lumnitzera racemosa & 137 & 0.99 & 10.95 & 7.62 & 7.28 & 25.85 \\
\hline Nypa fruticans & 77 & 1.72 & 6.51 & 4.48 & 4.28 & 15.27 \\
\hline Rhizophora mucronata & 47 & 2.09 & 3.98 & 7.2 & 6.9 & 18.08 \\
\hline Rhizophora stylosa & 80 & 3.34 & 6.69 & 8.95 & 12.85 & 28.48 \\
\hline Sonneratia caesolaris & 27 & 2.99 & 2.2 & 4.48 & 4.28 & 10.96 \\
\hline Sonneratia ovata & 33 & 1.53 & 2.91 & 2.72 & 2.62 & 8.25 \\
\hline Terminalia catappa & 13 & 1.3 & 1.17 & 4.11 & 3.95 & 9.23 \\
\hline Thespesia populnea & 53 & 5.59 & 4.47 & 4.48 & 4.28 & 13.23 \\
\hline Wedelia biflora & 17 & 0.33 & 1.42 & 1.33 & 1.28 & 4.04 \\
\hline Total & 1217 & 45 & 100 & 100 & 100 & 300 \\
\hline
\end{tabular}

Akbar et al. (2015) in Manomadeha island and Domretu Island, North Maluku found 11 species, and Akbar et al. (2016) found five species of mangroves on Mare Island, Tidore Islands, Karnanda et al. (2016) only found six species of mangroves on the coast of Pidie, Aceh Province.

While the results of the study of Muhtadi et al. (2020a) found 17 species in the Central Tapanuli Conservation Area, the number of these species is only lower than reported by Onrizal and Kusmana (2010) found 20 species of mangroves in Asahan Regency, Batubara Regency, and Serdang Bedagai Regency and Muhtadi et al. (2016) in Sambilan Island with 28 species. This is still possible where the east coast of Sumatra is more suitable for mangrove habitat with mud substrate and slow streamflow.

\subsection{Mangrove Importance Index (MII)}

Mangrove density in the Mangrove Ecosystems 
of Bagan Serdang Village is 1,217 ind /Ha on average. The highest mangrove density in Bagan Serdang Village is A. lanata and B. hainessi (Table 2). This density lower compared to other locations. Sitompul et al. (2014), obtained the density of mangroves in the Bali Beach, Batubara Regency with a range of 1,233 -1,400 ind / Ha. Hutabarat et al. (2015) obtained the density of mangroves in Labu Beach, Deli Serdang, with a value of $400-3,294$ ind / Ha. Muhtadi et al. (2020a) found mangrove densities in Tapian Nauli Bay ranged from 2,425 - 3,820 ind / Ha with an average of 3,120 ind / Ha and Mursala island ranged from 1,367 - 3,233 ind / Ha with an average of 2,356 ind / Ha. Likewise, the study results of Muhtadi et al. (2016) on The Sambilan island were much higher which reached 5,935 ind / Ha. The main environmental factors that affect mangrove density are tidal fluctuations and the average sea level height (Rangkuti et al., 2017).

Mangrove cover in Bagan Serdang Village is very low at $45 \mathrm{~cm}^{2} / \mathrm{Ha}$. Although the density is classified as moderate, the land coverage is classified as very low. This shows that the mangrove trees in Bagan Serdang Village are not thick. Not all high density makes the land coverage high. This is related to the age (height) of the trees. The results of the study of Muhtadi et al. (2016) in Sambilan island found that even with a high density on the west coast, it did not make the land cover of mangroves on the west coast high. This is because although mangroves on the west coast are tight, the types of mangroves found were smaller (trunk diameter) than those in the east. Although the numbers are small and the density is low, but the diameter of tree trunks found in the east is much bigger than in the west. This is why the land coverage of mangroves in the east is greater than in the west. A larger trunk diameter will be found with a greater height and thicker leaves so that the coverage becomes larger (Muhtadi et al., 2016).

The highest average MII of $A$. lanata species which reached 41.10 was followed by $B$. hainessi at 35.44 and A. ilicifolius at 32.97. These three species dominate the mangroves of Bagan Serdang Village. A. lanata is very dominant on the front area (sea), while $B$. hainessii and A. ilicifolius dominate land areas. The smallest IVI is owned by B. asiatica, C. Tagal, F. crenulata, and $W$. biflora species with values below 5 . However, despite their small influence each species contributes to the mangrove ecosystem of Bagan Serdang Village.

In general, the results of the importance value analysis of mangrove species indicate that $A$. lanata, $B$. hainessi and A. ilicifolius have an important influence and role in the mangrove community in Bagan Serdang
Village, Deli Serdang Regency. The three species are the main mangrove species that are always found and have a high density compared to other mangrove species. A. ilicifolius although categorized as shrub mangrove but has a quite large role compared to Ceriops mangroves species, for example, because it also has a large distribution in almost all observation points. Even at a certain point it is forming a kind of large carpet of Ceriops in the village of Bagan Serdang. Meanwhile $C$. decandra and E. agallocha have little influence in the community. This relates to the lack of trees and uneven distribution. Thus, the three species have a major role and big influence on the community and the mangrove ecosystem of Bagan Serdang Village.

\subsection{The Species Richness of Fauna}

The results of fauna identification in the mangrove ecosystem of Bagan Serdang Village were found 16 species of fish, nine species of crustaceans, 13 species of molluscs, four species of birds, one species of reptile, one species of mammal and one other species namely horseshoe crab (Table 3). Thus, as a complete ecosystem, organisms from producers (mangroves), consumers one and shredder (crustaceans and molluscs), consumers two (fish) to top predators are monitor lizards and birds. These organisms consist of aquatic (fish, molluscs and crustaceans) and terrestrial (birds, mammals, and reptiles).

The number of fish found is slightly more than those found on the east coast of North Sumatra, namely in Belawan (Medan) as many as 18 species from 17 families (Simbolon, 2014) and Jaring Halus (Langkat) as many as 19 species from 14 families (Puteri et al., 2017). In addition, it is lower than the Segoro Anak Area of the Alas Purwo National Park, 10 species (out of 10 families) (Latupapua, 2011), and 10 fish families in the Mangrove Ecosystem in Kedungmalang, Jepara (Redjeki, 2013). However, fewer than other locations, which is 20 families ( 32 species) in the mangrove waters of Ujung Kulon National Park (TNUK), (Wahyudewantoro and Haryono, 2011), 19 families in the Mangrove and Estuary Ecosystems in the Mangunharjo-Semarang and Morosari-Demak Areas (Suwartimah et al., 2013). Meanwhile, Rajpar and Zakaria (2014) recorded at least 106 species of fish that live around the mangrove area.

The mangrove area is a habitat that is a habitat suitable for the life of various types of aquatic invertebrates, including crustaceans and molluscs (Rajpar and Zakaria, 2014; Rangkuti et al., 2017). Crustaceans found in Bagan Serdang Village consist of shrimp groups from the Harpiosquillidae and Penaidae families and crab groups from the Portunidae and Ocypodidae families (Table 4). Shrimp found are important economic commodities 
Table 3. Fauna species found in mangrove ecosystem on Bagan Serdang Village

\begin{tabular}{|c|c|c|c|c|}
\hline No & Family & Species & Indonesia Name & Local Name \\
\hline \multicolumn{5}{|c|}{$\overline{\text { Fish }}$} \\
\hline 1 & Ariidae & Arius Thalassinus & Manyung & Manyung \\
\hline 2 & Engraulidae & Stolephorus indicus & Ikan teri pinggir & - \\
\hline 3 & Gobiidae & Boleophtalmus boddarti & Belodok & Tembakul \\
\hline 4 & Gobiidae & Periophthalmus gracilis & Belodok & Tembakul \\
\hline 5 & Gobiidae & Periopthalmonodon schlosseri & Belodok & Tembakul \\
\hline 6 & Hemiramphidae & Zenarchopterus buffonis & Julung-julung & - \\
\hline 7 & Latidae & Lates calcarifer & Kakap & - \\
\hline 8 & Leiognathidae & Leiognathus decorus & Peperek & - \\
\hline 9 & Leiognathidae & Leiognathus splendens & Peperek & - \\
\hline 10 & Lutjaniidae & Lutjanus johnii & Kakap & - \\
\hline 11 & Megalopidae & Megalops cyprinoides & Bulan-bulan & - \\
\hline 12 & Mugiliidae & Valamugil engeli & belanak & - \\
\hline 13 & Oryziidae & Oryzias javanicus & Lunjar & - \\
\hline 14 & Paralichthyidae & Pseudorhombus arsius & Ikan sebelah & - \\
\hline 15 & Sciaenidae & Johnius trachycephalus & Gulama & - \\
\hline 16 & Teraponidae & Terapon jorbua & Ikan terapon & - \\
\hline \multicolumn{5}{|c|}{ Crustacean } \\
\hline 17 & Grapsidae & Metopograpsus frontalis & Kepiting & - \\
\hline 18 & Grapsidae & Varuna litterata & Kepiting & \\
\hline 19 & Portunidae & Scylla paramamosain & Kepiting bakau & - \\
\hline 20 & Portunidae & Scylla serrata & Kepiting bakau & - \\
\hline 21 & Penaeidae & Penaeus indicus & Udang putih & - \\
\hline 22 & Penaeidae & Penaeus merguiensis & Udang jerbung & - \\
\hline 23 & Ocypodidae & Uca annulipes & - & - \\
\hline 24 & Ocypodidae & Uca coarctata & - & - \\
\hline 25 & Squillidae & Harpiosquilla raphidea & Udang mantis & - \\
\hline
\end{tabular}




\begin{tabular}{lllll}
\hline No & Family & Species & Indonesia Name & Local Name \\
\hline Mollusk & & & \\
26 & Corbioculidae & Polymesoda expansa & Kerang totok & Korang \\
27 & Potamiidae & Cerithidea obtuse & - & Keong \\
28 & Potamiidae & Cerithideopsilla alata & - & - \\
29 & Potamiidae & Telescopium telescopium & Keong bakau & - \\
31 & Arcidae & Anadara inaequivalvis & Kerang bulu & Korang \\
32 & Arcidae & Anadara gubernaculum & Kerang bulu & - \\
33 & Littorinidae & Littorina scabra & - & - \\
34 & Neritidae & Nerita balteata & - & - \\
35 & Neritidae & Nerita undata & - & - \\
36 & Strombidae & Strombus luhuanus & - & - \\
37 & Strombidae & Strombus sp. & - & - \\
38 & Naticidae & Natica tigrina & - & \\
\hline
\end{tabular}

\section{Bird}

39 Accipitridae

Ardea alba

Kuntul besar

40 Accipitridae

Egretta intermedia

Kuntul perak

41 Ardeidae

Haliastur indus

Elang bondol

42 Corvidae

Convus enca

Gagak hitam

43 Hirundinidae

Hirundo tahitica

Layang-layang

\section{Reptile}

$44 \quad$ Varanidae

Varanus salvator

Biawak

Biawak

Mammals

45. Cercopithecidae

Macaca fascicularis

Monyet ekor panjang

Kera

\section{Shoe horse crab}

46. Limulidae 
for mangrove inhabitants. Indian prawn and Banana shrimp are types of shrimp that are mostly found in estuarine waters and near mangrove areas (Pratiwi, 2009). Basically, the shrimp group spawns and nurtures in mangrove areas, and after they grow, they return to the sea (Katiresan, 2012; Igulu et al., 2014). Thus, a good mangrove condition will have an impact on shrimp production (Muhtadi et al., 2015). Other research results related to the presence of shrimp in the mangrove area include: Latupapua (2011) only found two types of shrimp, namely tiger shrimp (P. monodon), sweet/ white shrimp ( $P$. merguiensis) in the mangrove area of Segoro Anak Alas Purwo National Park. While Muhtadi et al. (2015) found P. penicillatus and P. semisulcatus in the silvofishery area of Subang, West Java. Yulianda et al. (2020a) found 18 crustaceans in the Siombak Lake mangrove ecosystem.

Shrimp are generally found in the waters (the front area), while mangrove crabs and uca in the back. This is in accordance with the findings of Pratiwi (2009) that crustaceans have a preference on the front part (sea). While S. paramamosain, S. olivacea and S. tranquebarica have preferences in the back and middle zone of the forest. $S$. serrata has preferences in the forest front zone, and the sea zone, and the uca group has preferences in the middle and rear area.
Molluses are a group of macrozoobenthos that are mostly found in mangrove ecosystems either submerged in the substrate, on the surface of the substrate, attached to the roots of mangroves, attached to the trunk and even attached to the mangrove leaves, especially mangrove seedlings or saplings (Rangkuti et al., 2017). Molluscs found in the mangrove area in the village of Bagan Serdang are 12 species from seven families, consisting of six gastropod types and six types of bivalves. Other research results in the mangrove area include Irma and Sofyatuddin (2012) found in 14 Gastropod species and five Bivalva species in mangrove rehabilitation ecosystems in Aceh Besar and Banda Aceh. Syahrial et al. (2019) found only four species in the Mangrove Reforestation Area of Pramuka, Island and Karya Island, Seribu Island, DKI Jakarta. Yulianda et al. (2020b) found nine molluscs in the tidal lake mangrove area in Medan.

\subsection{Diversity}

The diversity of mangroves in the Bagan Serdang Village mangrove ecosystem is categorized moderate, with a value of 1.63 . The moderate value of diversity affects the high similarity value $(>0.68)$ and with low dominance value $(<0.13)$. Although $A$. lanata, $B$. hainessi, and $A$. ilicifolius have a large role in the community (highest MII), it is not so dominant in the mangrove community in the mangrove ecosystem of Bagan

Table 4. Ecology index of flora and fauna in mangrove ecosystem on Bagan Serdang Village

\begin{tabular}{llll}
\hline Organism group & $\mathrm{H}^{\prime}$ & $\mathrm{E}$ & $\mathrm{C}$ \\
\hline Mangrove & 1.63 & 0.68 & 0.13 \\
Fish & 2.44 & 0.88 & 0.12 \\
Crustacean & 2.09 & 0.95 & 0.13 \\
Mollusc & 2.32 & 0.93 & 0.11 \\
Bird & 1.07 & 0.66 & 0.46 \\
\hline
\end{tabular}

Tabel 5. Activity achievements of the segmented project

\begin{tabular}{lllllc}
\hline Group & \multicolumn{1}{c}{ Type of production } & June & July & August & September \\
\hline Darwis & Nugget, fish shredded, fish ball & 110 & 130 & 130 & 130 \\
Darling & Mangrove syrup & 120 & 120 & 125 & 125 \\
PKK & Mangrove candy, Dodol Mangrove & 140 & 130 & 145 & 150 \\
P2WS & Dried shrimp dim sum, dried shrimp noodle & 125 & 130 & 140 & 140 \\
\hline
\end{tabular}


Serdang Village. This is because, in fact, if examined further, type A. lanata is only dominant in the front (near the sea). While on the back (near the mainland), nothing dominant. This is related to the presence of zoning in mangrove communities where certain types will grow according to the substrate and flooded frequency.

Meanwhile, the diversity of aquatic organisms in the Mangrove Ecosystems of Bagan Serdang Village is higher than the mangrove, namely 2.44 (fish), 2.32 (mollusc), and 2.09 (crustaceans). Therefore, although the diversity of mangroves is low, the diversity of aquatic organisms is quite high. Therefore, according to the statement of Rangkuti et al., (2017), mangroves are habitats of various aquatic organisms either as a place to look for food, spawning, and as a nursery area. While bird diversity is lower at 1.07 . The low diversity of birds could be due to already beginning to damage of the mangrove ecosystem and/or associated with the season. At certain times, the birds migrate to take shelter or find food.

\subsection{Mangrove ecosystem status}

Based on the standard criteria for mangrove damage, according to KLH (2004), showed that mangroves in the Mangrove Ecosystems of Bagan Serdang Village categorized in the medium category. This is due to the existence of some mangrove trees being cut down by a few people living in the location. In addition, many mangrove trees have experienced natural death, especially $A$. lanata due to freshwater supply and seawater failure entering the site.

Based on searches from various studies in Indonesia, it was found that the condition of mangroves was in the category of damaged to moderate, very few were found in good category and with abundant species. The results of Sitompul et al. (2014) on the Coast of Bali, Batu Bara Regency with a moderate category, Akbar et al. (2015) on the coast of Sidangoli, West Halmahera Regency, North Maluku obtained mangrove conditions in the damaged category, on Mare Island in Tidore islands found mangroves with moderate conditions (Akbar et al., 2016). It is not surprising that mangrove conditions in Indonesia suffered a lot of damage as reported by KLH (2012b), mangroves in Indonesia only 56\% are still in good category, and the rest are medium. Even in North Sumatra, $55.77 \%$ were damaged, and only $8.16 \%$ mangrove categorized good (KLH, 2012b). Mangrove conditions that are still good, as reported by Muhtadi et al. (2016; 2020a), were found in Sambilan Island and the Central Tapanuli Conservation Area (Tapian Nauli Bay and Mursala Island).

\subsection{CSR Implementation in Bagan Serdang Village}

Based on field observations, the mangrove ecosystem in the area of the mangrove ecosystem of Bagan Serdang Village has received threats from the activities of local residents. Therefore, through Pertamina's CSR, community-based, mangrove management efforts have been made. The focus of the community empowerment activities of Bagan Serdang mangrove village was as an ecotourism area in detail consists of five series of activities as follows:

1. Realization of the preservation and rehabilitation of mangrove plants by the local community in the Mangrove Village of Bagan Serdang

2. The realization of waves and abrasion retaining buildings to preserve and rehabilitate mangrove plants in Bagan Serdang Mangrove Village,

3. Diversification of processed mangrove products

4. The realization of buildings/kiosks as a place for marketing mangrove processed products, and

5. The realization of the mangrove's track pathway in Kampung Mangrove Bagan Serdang.

This conservation activity involves people who are joining in environmental awareness, tourism awareness, youth groups, and school students, by planting 3,000 mangrove trees in a land area of $13.47 \mathrm{Ha}$ (Figure 2). Out of the total planned planting of 7,000 mangrove trees, for the entire mangrove area to be rehabilitated, and continued planting of 20,000 mangroves in 2020 . The area of land that has been conserved in the form of mangrove trees planting covering $13.47 \mathrm{Ha}$ is a land area of moderate level of damage, with 3,000 mangrove trees planted that have been able to cover the damaged land area. Based on land area data that have not been conserved in the area of Bagan Serdang mangrove forest, it covers an area of $12.64 \mathrm{Ha}$, which is a coastal area and tidal area. Based on satellite imagery and ground facts, this area is a very badly damaged area, so more mangroves need to be planted. This activity will be carried out in the next.

Therefore it is hoped that the mangrove conditions in Bagan Serdang Village will be better. Thus through this CSR, it is hoped that this program will continue as part of the company's responsibility towards environmental sustainability. CSR is one of the efforts of funding from companies for the preservation of the natural environment (Regulation number 40, 2007). In addition, CSR is also expected to improve the economic condition of the community with assistance from the company (Firmansyah et al., 2018). 


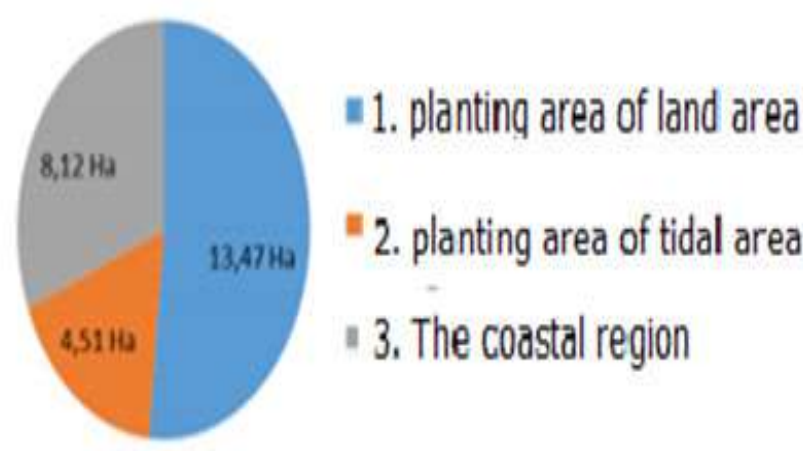

Figure 2. The area of mangrove conservation activity

\subsection{Economic impact}

Community empowerment activities in the village of Bagan Serdang, Pantai Labu sub-district through the mangrove ecotourism program, slowly had an impact on the community's economy. In the implementation of economic empowerment, skills development has been carried out for community groups as seafood and fruit processing, and mangrove leaves, these groups have produced various types of products including fish balls, nuggets, shredded fish, mangrove dodol, mangrove syrup, mangrove candy, ebi (dried shrimp) dimsum, ebi noodles, and others. From this production, there was an increase in community income of $10 \%$ (Figure 2) on average compared to before the assistance activities since carried out in June 2018. Thus mangroves can provide added value for improving the economic community, both processed mangrove, fisheries, and ecotourism (Rangkuti et al., 2017).

\section{Conclusion}

The results of the analysis of mangroves in the Bagan Serdang Village mangrove ecosystem are moderately damaged headed to damage. The diversity of mangroves in Bagan Serdang Village is lower (1.63) compared to aquatic organisms that reach $2.09-2.44$. Therefore, it needs better management of mangroves, especially the need for mangrove rehabilitation and establishment of the chart area Serdang into Park Biodiversity is essential for sustainable management. For CSR programs, the achievement of this activity becomes a strong foundation for the development and implementation of other relevant activities to make the Bagan Serdang Village an integrated ecotourism, icon especially in the Deli Serdang Regency. PT Pertamina (Persero) Fuel Terminal Medan Group maintains the mandate given by the community of Pantai Labu Sub-District,
Deli Serdang Regency, by proposing a further program that makes the Bagan Serdang Mangrove Village as the first community-based mangrove ecotourism model in the Sumatra region. Pertamina's CSR activities have an impact on environmental sustainability (as a habitat for various fauna) and improving the community's economy.

\section{Acknowledgement}

Thank you to PT Pertamina (Persero) Fuel Terminal Medan Group for funding research and CSR for the mangrove area of Bagan Serdang Village.

\section{Authors' Contributions}

All authors contribute to the process of data collection and writing of the manuscript. The contributions of the authors are: Muhtadi contributed to the idea, ecological data collection, data processing and draft writing of the manuscript. Leidonald contributed to ecological data collection and scriptwriting. Triwibowo and Azmi contribute to funders and economic data collection.

\section{Conflict of Interest}

The authors declare that they have no conflict of interest

\section{Funding Information}

This research was fully funded by PT Pertamina (Persero) Fuel Terminal Medan.

\section{Reference}

Anonimous. (2018a). Rencana Zonasi Wilayah Pesisir dan Pulau-pulau Kecil Provinsi Sumatera Utara. Medan: Dinas Kelautan dan Perikanan Provinsi Sumatera Utara.

Anonimous. (2018b). Laporan kegiatan Pemberdayaan Masyarakat Kampung Mangrove Bagan Serdang. Medan: Lembaga Pengabdian Kepada Masyarakat, Universitas Negeri Medan.

Akbar, N., Baksir, A., \& Tahir I. (2015). Mangrove Ecosystem Community Structure in The Coastal Area of Sidangoli, West Halmahera Regency, North Maluku. Depik, 4(3):132-143.

Akbar, N., Baksir, A., Tahir, I., \& Arafat, D. (2016). Mangrove Community Structure in Mare Island, The City of Tidore Island, North Maluku Province. Depik, 5(3): 133-142.

Bengen, D. G. (2004). Technical guidelines: introduction and management of mangrove ecosystems. Bogor: PKSPL-IPB. 
Carpenter, K. E., \& Niem, V. H. (1998). FAO Species Identification Guide for Fishery Purposes. The Living Marine Resources of the Western Central Pacific. Rome: Food and Agriculture Organization of the United Nations.

Dharma, B. (2005). Recent dan Fossil Indonesian Shell. Germany: Conchbooks.

DKP [Marine and Fisheries Agency] North Sumatra Province. (2015). Annual Report of Marine and Fisheries Agency of North Sumatra Province, Medan.

Firmansyah, A., Wulandari Y. P., \& Fitriana, D. (2018). Study of the Role of Kehati Park Kiara Payung To The Changes OF Environment And Social Community Village Sindangsari. Bogor: CARE LPPB IPB University.

Giesen, W., Wulffraat, S., Zieren, M., \& Schoelten, L. (2012). A Field Guide of Indonesian Mangrove. Bogor: Wetlands International - Indonesia Programme.

Hartini, S., Saputro, G. B., Yulianto, M., \& Suprajaka. (2010). Assessing the Used of Remotely Sensed Data for Mapping Mangroves Indonesia. In Selected Topics In Power Systems And Remote Sensing. Iwate Prefectural University, Japan. October 4-6, 2010. Japan: WSEAS Press.

Hutabarat, D., Yunasfi, \& Muhtadi, A. (2015). Mangrove ecological conditions in Putra Deli Beach, Denai Kuala Village, Labu Beach District, Deli Serdang Regency, North Sumatra Province. Aquacostmarine, 3(5): 141-148.

Igulu, M. M., Nagelkerken, I., Dorenbosch, M., Grol, M. G. G., \& Harborne, A. R. (2014). Mangrove Habitat Use by Juvenile Reef Fish: Meta-Analysis Reveals that Tidal Regime Matters More than Biogeographic Region. PLoS ONE, 9 (12): e114715. doi:10.1371/journal.pone.0114715.

Irfandi. (2018). Laporan kegiatan Pemberdayaan Masyarakat Kampung Mangrove Bagan Serdang. Medan: Lembaga Pengabdian Kepada Masyarakat, Universitas Negeri Medan.

Irma, D., \& Sofyatuddin, K. (2012). Diversity of Gastropods and Bivalves in mangrove ecosystem rehabilitation areas in Aceh Besar and Banda Aceh districts, Indonesia. AACL Bioflux, 5 (2): 55-59. http://www.bioflux.com.ro/aacl.

Karnanda, M., Muchlisin, Z. A., \& Sarong, M. A. (2016). Mangrove community structure and management strategy in Pidie Regency, Aceh Province. Depik, 5(3): 112-127.

Kathiresan, K. (2012). Importance of Mangrove Ecosys- tem. International Journal of Marine Science, 2 (10): 70-89. DOI: 10.5376/ijms. 2012.02.0010.

Kottelat, M., Whitten A. J., Kartikasari, S. N., \& Wirjoatmodjo, S. (1993) Freshwater fishes of western Indonesia and Sulawesi. Jakarta: Periplus Editions Limited.

KLH [Ministry of Environment]. (2004). Decree of the State Minister for the Environment No. 201/2004, concerning standard criteria and guidelines for determining mangrove damage. Jakarta: Ministry of the Environment.

KLH [Ministry of Environment]. (2012a). Ministry regulation Nomber 3 Environment About the Biodiversity Park. Jakarta: Ministry of Environment.

KLH [Ministry of Environment]. (2012b). Indonesia Environment Status 2012. Jakarta: State Ministry of Environment.

KLHK [Ministry of Environment and Forestry]. (2015). 10 Location Profile of Taman Kehati. Jakarta: State Ministry of Environment.

KLHK [Ministry of Environment and Forestry]. (2017). Press release number: SP. 58 / HUMAS / PP / HMS.3 / 03/2017: Owns 23\% of the world's mangrove ecosystem, Indonesia is hosting a 2017 international mangrove conference. Jakarta: Public Relations Bureau of the Ministry of Environment and Forestry.

Krebs, C. J. (2014). Ecological Methodology 3rd. University of British Columbia. Harper Collins Publisher, New York.

Latupapua, M. J. J. (2011). Diversity of nekton species in the mangroves of the Segoro Anak area of the Alas Purwo National Park. Jurnal Agroforestri, 6 (2): 81-91.

Muhtadi, A., Soewardi, K., \& Taryono. (2015). Ecological status and development of Minawana for improving the community's economy (Case Study: Minawana Area, Tegal-Tangil RPH, Purwakarta KPH, Blanakan Subang, West Java). Acta Aquatica, 2(1): 41-47.

Muhtadi, A., Siregar, R. H., Leidonald, R., \& Harahap, Z. A. (2016). Mangrove ecological status Sembilan Island, Langkat Regency, North Sumatra Province. Depik, 5(3): 151-163. DOI: 10.13170/ depik.5.3.5656.

Muhtadi, A., Harahap, Z. A., Pulungan, A., Nurmatias, Lubis, P., Siregar, Z., Ompusunggu, R. Y., \& Aulia, F. (2020a). Status and distribution of mangroves in the Taman Pulau Kecil Conservation Area, Tapanuli Tengah Regency, North 
Sumatra Province. Depik (in press).

Muhtadi, A., Yulianda, F., Boer, M., \& Krisanti, M. (2020b). Spatial Distribution of mangroves in tidal lake ecosystem. IOP Conf. Series: Earth and Environmental Science (in press).

Odum, E. P. (1996). Fundamental Ecology 3rd. translator: Samingan, T. Yogyakarta : UGM Press.

Onrizal, \& Kusmana, C. (2010). Study of the ecology of mangrove forests on the east coast of North Sumatra. Biodiversitas, 9(1): 25-29.

Puteri, D., Sirorus, H., \& Muhtadi, A. (2017). Fish diversity at mangrove ecosystem of Jaring Halus Village in Langkat Regency, North Sumatera. Depik, 6 (2): 145-152. DOI: 10.13170/depik.6.2.6656,

Pratiwi, R. (2009). The composition of the presence of crustaceans in the mangrove Delta Mahakam East Kalimantan. Makara Sains, 13 (1): 65-76.

Rangkuti, A. M., Cordova, M. R., Rahmawati, A., Yulma, Adimu, E. H. (2017). Indonesian Coastal and Marine Ecosystems. Jakarta: PT. Bumi Aksara.

Rajpar, M. N., Zakaria, M. (2014). Mangrove fauna Asia. In: Hanum IF, Latif A, Hakeem KR, Ozturk M (eds) Mangrove ecosystems of Asia. New York, Springer Science, 153-197. DOI 10.1007/978-1-4614-8582-7_8.

Redjeki, S. (2013). Composition and abundance of fish in the Mangrove Ecosystem in Kedungmalang, Jepara. Ilmu Kelautan, 18 (1): 54-60.

Regional Regulation Number 4 of 2019 (2019) Concerning Zoning Plan for Coastal Areas and Small Islands of North Sumatra Province.

Regulation of The Republic of Indonesia Number 40 of 2007 (2007) Concerning Limited Company

Samsumarlin, Rachman, I., \& Toknok, B. (2015). Study of estuary mangrove zoning in Umbele Village,
Bumi Raya District, Morowali Regency, Central Sulawesi. Warta Rimba, 3(2): 148-154.

Simbolon, J. N. (2014). The diversity and distribution of fish in aquatic estuary Belawan in North Sumatera. [Master thesis]. Medan: University of Sumatera Utara. $48 \mathrm{p}$.

Sitompul, O. S., Yunasfi, \& Muhtadi, A. (2014). Mangrove ecological conditions on the coast of Bali Mesjid Lama Village Talawi District Batu Bara Regency North Sumatra Province. Jurnal Mitra Bahari, 8(2): 15-27.

Suwartimah, K., Zainuri, M., \& Pribadi, R. (2013). The existence of Fish Populations in Mangrove and Estuary Ecosystems in the Mangunharjo-Semarang and Morosari-Demak Regions. Paper presented at the Third National Seminar on Fisheries and Marine Research Results FPIK-Universitas Diponegoro, Semarang.

Syahrial, Neneng, P., Herlina, A. D. M. U. S., Nur, A., Yuliana, S., Bayu, O., \& Novhitasari, S. (2019). Enviromental characteristics and conditions of macrobentic fauna in the mangrove reforestation area of Pramuka, Panggang, and Karya Island, Seribu Island, Indonesia. Jurnal Ilmiah Perikanan dan Kelautan, 11(1):9-20.

Wahyudewantoro, G., \& Haryono. (2011). Fish mangrove areas on several rivers around the Ujung Kulon National Park, Pandeglang: a review of the rainy season. Bionatura, 13 (2): 217 - 225.

Yulianda, F., Muhtadi, A., Boer, M., Krisanti, M., \& Wardiatno Y. (2020a). Biological conservation of mollusc based on spatial and temporal in tropical tidal lake, Medan Indonesia. Biodiversitas (in press).

Yulianda, F., Muhtadi, A., Boer, M., Krisanti, M., \& Wardiatno Y. (2020b). Biological conservation of mollusc based on spatial and temporal in tropical tidal lake, Medan Indonesia. Hayati Journal Bioseciences, (in press). 